DOI: $10.2478 /$ acas-2013-0013

Agrovoc descriptors: soft wheat, triticum aestivum, crop yield, water deprivation, water depletion, spikes, source sink relations, drought stress, drought resistance

Agris category code: f01, f50, f60

\title{
Effect of source and sink limitation on yield and some agronomic characteristics in modern bread wheat cultivars under post anthesis water deficiency
}

\author{
Majid ABDOLI ${ }^{1 *}$, Mohsen SAEIDI², Saeid JALALI-HONARMAND², Sirus MANSOURIFAR ${ }^{2}$, Mohammad- \\ Eghbal GHOBADI ${ }^{2}$, Kianoush CHEGHAMIRZA ${ }^{2}$
}

Received April 09, 2013; accepted September 03, 2013.

Delo je prispelo 09. aprila 2013, sprejeto 03. septembra 2013.

\begin{abstract}
In order to examine the effect of source and sink limitation and post anthesis water deficiency stress in determining of grain yield potential in nine modern bread wheat cultivars in the west of Iran with arid and semi-arid weather that is one of the main centers of crop diversity in the world, a split plot-factorial experiment based on randomized complete block design with three replications was used in crop year 2010-2011. Three treatments includes: control, flag leaf removal and removal of half of each spike was applied in the field research campus of agriculture and natural resources of Razi University. Water deficiency stress was started at anthesis and continued till physiological maturity (withholding of irrigation). Water deficiency caused significant reduction in the grain yield and the 1000 grain weight and caused significant increase in the number of fertile spikelets per spike. Flag leaf removal (source limitation) treatments showed that flag leaf contribution in grain yield production during grain filling in control and post-anthesis water deficiency stress condition were $10.1 \%$ and $13.4 \%$ respectively. In both conditions removal of spikelets spike ${ }^{-1}$ (sink limitation) treatment had higher significant effect on fertility of spikelets, grains $\operatorname{spike}^{-1}$, grain yield spike $^{-1}$ and 1000 grain weight than flag leaf removal. Flag leaf removal treatment in some cultivars not only had no reduction effect on grain yield and 1000 grain weight but also increased them. These results may be due to an increase in photosynthesis rate of remaining leaves and/or increase in amount of carbohydrates remobilization that is stored in the stems. This phenomenon is called the compensatory effect. In both water regimes, there was a correlation between lower grain weight, no grains spike ${ }^{-1}$ and fertile spikelet spike ${ }^{-1}$ and lower yield potential of 'Chamran' cultivar. But, 'Zarin' and 'Pishgam' cultivars due to higher grain yield potential in post-anthesis under water deficiency stress and control, performed more studies, to advise farmers to cultivate them. There are probably better than any other cultivars that are common in these regions and sowing of them by farmers will be associated with less risk.
\end{abstract}

Key words: wheat, grain yield, water deficiency, source, sink, flag leaf, spike

\section{IZVLEČEK}

OMEJITVENI VPLIV VIRA IN PONORA NA PRIDELEK IN NEKATERE AGRONOMSKE LASTNOSTI NOVEJŠIH SORT KRUŠNE PŠENICE V RAZMERAH POMANJKANJA VODE PO ANTEZI

Za preučevanje omejitvenega učinka vira in ponora $\mathrm{v}$ razmerah pomankanja vode po antezi na potencial pridelka zrnja pri devetih novejših sortah krušne pšenice je bil v zahodnem Iranu, s sušnim in polsušnim podnebjem, na območju enega izmed glavnih centrov diverzitete kulurnih rastlin, izveden "split-plot" faktorski poskus, temelječ na naključno izbranih blokih $\mathrm{v}$ treh ponovitvah $\mathrm{v}$ pridelovalni sezoni 2010-2011. Tri obravnavanja so obsegala: kontrolo, odstranitev najvišjega lista ("zastavarja") in odstranitev polovice vsakega klasa na raziskovalnem polju Kampusa za agronomijo in naravne vire Razi univerze. Stres pomanjkanja vode je nastopil ob antezi s prekinitvijo namakanja in je trajal do fiziološke zrelosti. Pomanjkanje vode je povzročilo značilno zmanjšanje pridelka zrnja, zmanjšanje teže $1000 \mathrm{zrn}$ in značilno povečanje števila fertilnih klaskov na klas. Odstranitev lista zastavarja (omejitev vira) je pokazala, da ta prispeva pridelku zrnja $\mathrm{v}$ obdobju polnjenja zrn $\mathrm{v}$ kontroli in $\mathrm{v}$ poanteznem stresu pomankanja vode $10.1 \%$, oziroma $13.4 \%$. V obeh razmerah je imela odstranitev klaskov v klasu (omejitev ponora) večji značilni vpliv na fertilnost klaskov, število zrn na klas, pridelek zrnja na klas in na težo 1000 zrn kot odstranitev lista zastavarja. Odstranitev lista zastavarja pri nekaterih sortah ne samo, da ni zmanjšala pridelka zrnja in teže 1000 zrn ampak ju je celo povečala. To bi lahko bilo posledica povečanja fotosinteze preostalih listov in /ali povečanja količine sproščenih ogljikovih hidratov iz zalog v steblu. Ta pojav se imenuje nadomestni učinek. $\mathrm{V}$ obeh vodnih režimih je bila korelacija med parametri kot so manjša teža zrnja, nič zrn na klas in fertilnimi klaski na klas z manjšim potencialom pridelka pri sorti 'Chamran'. Toda s sortama 'Zarin' in 'Pishgam', bi bilo zaradi njunega večjega potenciala v pridelku zrnja v razmerah sušnega stresa po cvetenju kot $\mathrm{v}$ kontroli, potrebno opraviti še več poskusov predenj bi svetovali kmetom njuno pridelovanje. Ti dve sta verjetno boljši kot katerakoli druga sorta, ki so pogoste v tem območju, in njuno sejanje bi kmetom povzročilo manjše tveganje glede na okoljske strese.

Ključne besede: pšenica, pridelek zrnja, pomanjkanje vode, vir, ponor, list zastavar, klas

\footnotetext{
Young Researchers and Elite Club, Zanjan Branch, Islamic Azad University, Zanjan, Iran, *Corresponding author, Email: majid.abdoli64@yahoo.com

2 Department of Agronomy and Plant Breeding, Campus of Agriculture and Natural Recourse, Razi University, Kermanshah, Iran
} 


\section{INTRODUCTION}

Wheat (Triticum aestivum L.) is one of the most important food resources. This plant is cultivated in a wide range in agricultural land of the world (Royo et al., 2005). Approximately one third of the world population is using this plant as main food (Gallagher, 1984).

Different types of abiotic environmental stresses cause reduction in quantity and quality of wheat grain yield production (Jones, 2009). Among different types of abiotic environmental stresses, water stress is the most important factor in limiting wheat growth and grain yield formation (Ercoli et al., 2007). Due to the geographical situation, Iran's climate is Mediterranean and with respect to average participation $(240 \mathrm{~mm})$, is considered as arid and semi-dry regions of the world (HeidariSharifabad, 2008). Flowering and grain filling of wheat are the most sensitive stages to environmental stresses such as water stress (Winkel, 1989). Water stress in such areas often occurs during these periods. Under such conditions, providing of carbohydrates that are needed for grain filling to form the economical yield is very important. The most important factor in reducing grain yield in such areas is grain weight reduction (Saeidi et al., 2010).

Grain yield is a complex trait and influenced by many factors. So, to enhance grain yield production in wheat, determining factors should be identified (Acreche and Slafer, 2006). For breeders, determination of source and sink limitation in grain yield production of wheat is very important. So far, despite the importance of source and sink limitation in grain yield production of wheat, there has been little discussion about them especially in different bread wheat cultivars of Iran.

Leaves and spikes in wheat are two main photosynthetic tissues and have very important roles in grain filling and yield production (Birsin, 2005). Movement of photo-assimilates from sources (leaves, spikes and stems) to sinks (grains) are dependent on both source and sink strength (Fischer et al., 1977). Water stress during grain growth by creating of imbalance between source and sink strength caused reduction in grain yield.
Wardlaw (1980) demonstrated that if photoassimilates are not used in physiological sinks, photosynthetic production of photo-assimilates is reduced as a result of the feedback. Also Wardlaw (1980), Fischer et al. (1977) and Blum et al. (1988) concluded that, one way to increase grain yield in wheat is manipulation of sink (grain) capacity. In another major study, Miralles and Slafer (1995) found that in dwarf cultivars of wheat under water stress condition by reducing number of spikelets (artificial removing), the weight of remaining grains was increased. But this result was not found in long-legged cultivars. Increasing of grain weight and grain yield of wheat cultivars under removal of some spikelets in each spike was expressed in other reports (Calderini and Reynolds, 2000; Mahfoozi and Jasemi, 2010). In relation to source limitation, Zhu et al. (2004) found that in wheat cultivars, leaves defoliation at the early and the mid of tillering stage had no significant effect on grain yield production, but at the stage of tillering and at the jointing it significantly reduced it.

Whether, limiting factors in grain yield production at sink or source levels are dominant, is an issue that is still discussed (Cruz-Aguado et al., 1999). So that, some researchers have expressed that the grain yield of wheat is limited by the source (Duggan et al., 2000; Radmehr et al., 2004; Saeidi et al., 2012) or sink strength (Blum et al., 1983; Borra's et al., 2004; Reynolds et al., 2007; Fischer, 2008), while some researchers have emphasized the concurrent limitations of source and sink (Aggarwal et al., 1986). These disagreements are probably because of differences in cultivars, environmental conditions and application time of treatments.

Due to occurrence of water deficiency stress after anthesis each year and reduction yield potential of different wheat cultivars in arid and semi-arid regions of world such as most of the areas in the western region of Iran, the objectives of this research are to determine the roles of source and sink limitations on formation of grain yield and its components in different improved wheat cultivars that are treated with water deficiency stress. 


\section{MATERIALS AND METHODS}

The present study was conducted during 20102011 in the field research of Razi university in Kermanshah state in the west of Iran $\left(47^{\circ} 9^{\prime} \mathrm{E}\right.$ and $\left.34^{\circ} 21^{\prime} \mathrm{N}\right), 1319$ meters above sea level. The research was conducted on a field where the previous crop was a corn. The soil is a clay loam (36.1\% clay, $30.7 \%$ silt) and the experiment was laid out in a split plot design arranged in a randomized complete blocks with three replications. Factors evaluated were moisture regimes (two levels), bread wheat cultivars (nine levels) and source/sink limitation (three levels). Moisture regimes as the main-plot factor included (1) irrigation in all stages of plant growth and (2) post-anthesis water deficiency with withholding of irrigation. Tested cultivars (subplot factor) were different improved bread cultivars: 'Bahar', 'Parsi', 'Pishtaz', 'Pishgam', 'Chamran', 'Zarin', 'Sivand', 'Marvdasht' and 'DN-11'. And also sink and source limitation treatments as sub-plot were considered. For the application of sink and source limitation during flowering in the middle rows of each plot for each cultivar 15 similar stems were selected and following three treatments were applied for five out of 15 stems: (1) control, (2) removing flag leaves (source limitation treatment) and (3) removing spikelets on one side of each spike using the forceps (sink limitation).
The investigated cultivars were chosen because of their contrasting grain yield productivity and the highest area under cultivation in the west of Iran. Also, post-anthesis water deficit occurr almost every year of in cultivated area in these regions. Date of anthesis was determined from middle rows in each plot when $50 \%$ of the spikes had extruded anthers (Ehdaie et al., 2006 a). Each plot included 54 rows $20 \mathrm{~cm}$ apart, 4 meters long, 4 and 3 meters distances were taken between test plots and replicates, respectively. Seeds were sown at a density of 400 seeds $\mathrm{m}^{-2}$ on $12^{\text {th }}$ October. Based on soil analysis, nitrogenous fertilizer as urea $\left(\mathrm{CO}\left(\mathrm{NH}_{2}\right)_{2}\right)$ was applied prior to planting, as topdressing at tillering stage and at flowering stage, $80 \mathrm{~kg} \mathrm{~N} / \mathrm{ha}$ in each stage. At economical maturity, number of grain spike $^{-1}$, grain weight spike $^{-1}$, number of fertile and infertile spikelet spike $^{-1}$ and 1000 grain weight in each treatment in five spikes were calculated.

The Analysis of variance using MSTATC and SAS soft-wares was performed for each parameter measured or calculated. The means were compared using the least significant differences (LSD) test at level of 0.05 probability (Steel et al., 1997). Weather conditions during the crop season are presented in Table 1 .

Table 1. Minimum and maximum of temperature and relative humidity also precipitation in the Kermanshah region in the west of Iran during 2010-2011.

\begin{tabular}{|c|c|c|c|c|c|}
\hline \multirow[t]{2}{*}{ Month } & \multicolumn{2}{|c|}{$\begin{array}{c}\begin{array}{c}\text { Average of temperature } \\
\left({ }^{\circ} \mathrm{C}\right)\end{array} \\
\end{array}$} & \multirow{2}{*}{$\begin{array}{l}\text { Monthly total of precipitation } \\
\text { (mm) }\end{array}$} & \multicolumn{2}{|c|}{$\begin{array}{c}\text { Average of relative humidity } \\
(\%)\end{array}$} \\
\hline & minimum & maximum & & minimum & maximum \\
\hline Oct. & 10.6 & 30.3 & 1 & 13.2 & 46.4 \\
\hline Nov. & 4.5 & 21.9 & 31 & 22.8 & 66.8 \\
\hline Dec. & -1.5 & 16.8 & 24 & 26.5 & 62.4 \\
\hline Jan. & -2.2 & 9.6 & 50 & 47.1 & 91.0 \\
\hline Feb. & -2.7 & 8.0 & 65 & 52.1 & 94.2 \\
\hline Mar. & 0.6 & 15.4 & 21 & 28.1 & 82.0 \\
\hline Apr. & 4.5 & 20.1 & 47 & 24.6 & 78.8 \\
\hline May. & 9.5 & 23.6 & 128 & 33.6 & 87.4 \\
\hline Jun. & 12.8 & 33.8 & 0 & 11.3 & 51.1 \\
\hline Jul. & 17.1 & 38.5 & 0 & 6.6 & 32.1 \\
\hline Aug. & 18.1 & 39.5 & 0 & 6 & 27.7 \\
\hline Sep. & 13.8 & 34.6 & 0 & 7.8 & 32.0 \\
\hline
\end{tabular}




\section{RESULTS AND DISCUSSION}

\subsection{Cultivar evaluated in terms of yield and its components}

According to the results of mean comparisons, the highest grain yield under both control and post anthesis water deficiency was observed for 'Zarin' and 'Pishgam' cultivars and the lowest for 'Chamran' cultivar (Table 2). Post anthesis water deficiency stress significantly reduced the grain yield (18\%), the 1000 grain weight $(20 \%)$ and significantly increased the number of fertile spikelet per spike (3\%) in evaluated cultivars (Table 2). There are similarities between the results observed in this study and those described in literature such as: Shah and Paulsen (2003), Yang and Zhang (2006), Ehdaie et al. (2006 b) and Saeidi et al. (2010).

Significant reduction of 1000 grain weight in evaluated cultivars in response to post anthesis water deficiency stress as seen in this study, probably reflects the lack of an adequate supply of photo-assimilates that needed for grain filling during grain growth. This finding is in agreement with Ahmadi et al. (2009 a).
Different responses of 1000 grain weight of cultivars to post-anthesis water deficiency stress in this research showed that there was different sensitivity or resistance to post-anthesis water deficiency among cultivars. Greatest reduction in 1000 grain weight after exposure to post-anthesis water deficiency was seen in 'Zarin' and 'Marvdasht' (32.1 and $28.6 \%$ ) cultivars and lowest reduction was seen in 'Pishgam' and 'Chamran' (11.7 and 13.5\%) cultivars (Table 5). Between control and stress conditions, in terms of the number of grains spike $^{-1}$ there was no significant difference. This result is probably due to the fact that the potential of this component is formed before anthesis. These results are consistent with those of other studies such as Kobata et al. (1992), Araus et al. (2002), Shah and Paulsen (2003) and Tavakoli et al. (2009). In terms of the number of grain spike $^{-1}$, significant differences were observed between cultivars. 'Zarin' cultivar had the highest (59 grain spike ${ }^{-1}$ ) and 'Chamran' cultivar had the lowest (36.4 grain spike $^{-1}$ ) value in both water regimes (Table 2).

Table 2: Mean comparisons of agronomic traits in wheat cultivars under well water and post-anthesis water deficiency stress.

\begin{tabular}{|c|c|c|c|c|c|}
\hline Traits & $\begin{array}{l}\text { Grain yield } \\
\text { (g/spike) }\end{array}$ & $\begin{array}{l}1000 \text { grain } \\
\text { weight (g) }\end{array}$ & Grain spike $^{-1}$ & $\begin{array}{l}\text { Fertile } \\
\text { spikelet }\end{array}$ & $\begin{array}{l}\text { Non fertile } \\
\text { spikelet }\end{array}$ \\
\hline \multicolumn{6}{|l|}{ Irrigation } \\
\hline Water & $1.96 \mathrm{a}$ & $43.3 \mathrm{a}$ & $45.4 \mathrm{a}$ & $16.2 \mathrm{~b}$ & $1.99 \mathrm{a}$ \\
\hline Stress & $1.61 \mathrm{~b}$ & $34.7 \mathrm{~b}$ & $46.5 \mathrm{a}$ & $16.7 \mathrm{a}$ & $1.67 \mathrm{a}$ \\
\hline decrease $(\%)$ & -17.9 & -19.9 & 2.53 & 2.84 & -16.1 \\
\hline \multicolumn{6}{|l|}{ Cultivars } \\
\hline Bahar & $1.83 \mathrm{~b}$ & $37.8 \mathrm{c}$ & $48.4 \mathrm{c}$ & $17.7 \mathrm{a}$ & $1.61 \mathrm{e}$ \\
\hline Parsi & $1.56 \mathrm{ef}$ & $40.6 \mathrm{~b}$ & $38.4 \mathrm{de}$ & $15.5 \mathrm{c}$ & $2.51 \mathrm{~b}$ \\
\hline Pishtaz & $1.67 \mathrm{cde}$ & $42.6 \mathrm{a}$ & $36.2 \mathrm{~d}$ & $15.1 \mathrm{c}$ & $2.11 \mathrm{~cd}$ \\
\hline Pishgam & $2.20 \mathrm{a}$ & $41.2 \mathrm{ab}$ & $53.1 \mathrm{~b}$ & $17.7 \mathrm{a}$ & $1.17 \mathrm{f}$ \\
\hline Chamran & $1.48 \mathrm{f}$ & $40.8 \mathrm{ab}$ & $36.4 \mathrm{e}$ & $15.5 \mathrm{bc}$ & $3.18 \mathrm{a}$ \\
\hline Zarin & $2.18 \mathrm{a}$ & $36.5 \mathrm{c}$ & $59.0 \mathrm{a}$ & $17.7 \mathrm{a}$ & $1.05 \mathrm{f}$ \\
\hline Sivand & $1.62 \mathrm{de}$ & $41.5 \mathrm{ab}$ & $38.9 \mathrm{de}$ & $15.1 \mathrm{c}$ & $2.28 \mathrm{bc}$ \\
\hline Marvdasht & $1.78 \mathrm{bc}$ & $32.6 \mathrm{~d}$ & $54.1 \mathrm{~b}$ & $17.4 \mathrm{a}$ & $0.62 \mathrm{~g}$ \\
\hline DN-11 & $1.70 \mathrm{~cd}$ & $37.1 \mathrm{c}$ & $45.9 \mathrm{c}$ & $16.2 \mathrm{~b}$ & $1.86 \mathrm{de}$ \\
\hline \multicolumn{6}{|l|}{ Treatments } \\
\hline Control & $1.68 \mathrm{~b}$ & $37.7 \mathrm{~b}$ & $45.4 \mathrm{~b}$ & $16.4 \mathrm{~b}$ & $2.25 \mathrm{a}$ \\
\hline Remove flag leaf & $1.49 \mathrm{c}$ & $36.1 \mathrm{c}$ & $41.9 \mathrm{c}$ & $15.1 \mathrm{c}$ & $1.73 \mathrm{~b}$ \\
\hline Remove one side spike & $2.16 \mathrm{a}$ & $43.2 \mathrm{a}$ & $50.6 \mathrm{a}$ & $17.8 \mathrm{a}$ & $1.49 \mathrm{c}$ \\
\hline
\end{tabular}

Means in each column followed by at least one similar letter are not significantly different at $5 \%$ probability level, using LSD Test. 
Under well-watered and post-anthesis water deficiency stress there were significant differences between cultivars in term of fertile spikelets per spike. Post-anthesis water deficiency significantly decreased fertile spikelet spike ${ }^{-1}$ (Table 2 ). In both control and post anthesis water deficiency stress 'Zarin', 'Marvdasht', 'Bahar' and 'Pishgam' cultivars had the highest and 'Sivand' and 'Pishtaz' cultivars had the lowest fertile spikelets per spike. Post-anthesis water deficiency had no significant effect on infertile spikelet spike ${ }^{-1}$ but in terms of this treat there were significant differences among of cultivars. In terms of numbers infertile spikelets 'Chamran' and 'Marvdasht' cultivars had the highest and the lowest values respectively (Table 2 ).

Despite lower grain yield of 'Chamran' cultivar than other cultivars in both conditions, water deficiency caused the lowest reduction in grain yield of this cultivar. So, using of this cultivar for physiological studies and finally transfers of its resistance traits to high-yield cultivars but sensitive to post-anthesis water stress can be useful. In both water regimes, there was a correlation between lower grain weight, no grains spike ${ }^{-1}$ and fertile spikelet spike $^{-1}$ and lower yield potential of 'Chamran' cultivar (Table 5). But, 'Zarin' and 'Pishgam' cultivars due to higher grain yield potential in post-anthesis water deficiency stress and control, after more studies, to advise farmers to cultivate are probably better than any other cultivars that are common in these regions and sowing of them by farmers will be associated with less risk.

\subsection{Flag leaf removal treatment}

The results showed the flag leaf removal in the control and stress after anthesis conditions reduced grain yield per spike, 1000 grain weight, grain number per spike and number of spikelets was fertile and infertile (Table 2). Similary, a loss of yield caused by removal of the flag leaf has been reported by Biade and Baker (1991) and Radmehr et al. (2004). Reduced yield and 1000 grain weight removal in the flag leaf this suggests that important role in the flag leaf photosynthesis and grain filling. In this connection Cruz-Aguado et al. (1999) and Biade and Baker (1991) reports leaves, especially flag leaf as source material for production of photosynthetic and the most influential factors on the growth of the reservoir (seeds). The flag leaf removal in the control and stress after anthesis conditions reduce the yield spike, respectively 10.1 and $13.4 \%, 1000$ grain weight 2.2 and $7.1 \%$, number of grains per spike 8.4 and $7.2 \%$, number of fertile spikelets 9.2 and $7.5 \%$ and number of non-fertile spikelets 23.8 and $22.2 \%$ toward control condition (Table 3 ). Reduce the number of grains per spike, 1000 grain weight and grain yield due to defoliation in other reports including Birsin (2005) and Alam et al. (2008). In this context Mohamadtaheri et al. (2010) in their research on cultivar of wheat were effect of defoliation on the number of grains per spike Significant but here was no significant effect on 1000 grain weight. Esmaielpur (2007) with no significant decrease in yield due to reduced power source the removal of leaves in the wheat.

Table 3: Variation in mean yield and its components in bread wheat cultivars as affected by the removal flag leaf and unremoval flag leaf treatments under well-water and water stress after anthesis conditions

\begin{tabular}{lcccccc}
\hline & \multicolumn{3}{c}{ Well water } & \multicolumn{2}{c}{ Water stress after anthesis } \\
\cline { 2 - 7 } \multicolumn{1}{c}{ Traits } & Control & $\begin{array}{c}\text { Remove } \\
\text { the flag } \\
\text { leaf }\end{array}$ & $\begin{array}{c}\text { Changes of } \\
\text { control } \\
(\%)\end{array}$ & $\begin{array}{c}\text { Remove } \\
\text { the flag } \\
\text { leaf }\end{array}$ & $\begin{array}{c}\text { Changes of } \\
\text { control } \\
(\%)\end{array}$ \\
\hline Grain yield (g/spike) & $1.87 \pm 0.10$ & $1.69 \pm 0.09$ & 10.1 & $1.50 \pm 0.06$ & $1.30 \pm 0.06$ & 13.4 \\
1000 grain weight (g) & $42.3 \pm 1.2$ & $41.4 \pm 1.0$ & 2.2 & $33.1 \pm 1.4$ & $30.7 \pm 1.2$ & 7.1 \\
Grain spike-1 & $44.8 \pm 3.0$ & $41.0 \pm 2.5$ & 8.4 & $46.0 \pm 2.7$ & $42.7 \pm 2.1$ & 7.2 \\
Fertile spikelet & $16.2 \pm 0.4$ & $14.7 \pm 0.5$ & 9.2 & $16.6 \pm 0.5$ & $15.4 \pm 0.4$ & 7.5 \\
Non fertile spikelet & $2.45 \pm 0.30$ & $1.87 \pm 0.29$ & 23.8 & $2.05 \pm 0.27$ & $1.60 \pm 0.26$ & 22.2 \\
\hline
\end{tabular}

Data were means \pm SE.

Results of the flag leaf removal treatments on grain yield per spike in control (no stress) conditions showed, in applying this treatment in 'Chamran' and 'Pishgam' cultivar grain yield was not reduced even increased the amount 4.8 and $3.7 \%$, the cultivar were respectively but in the 'Pishtaz', 
'Sivand' and 'DN-11' this treatment caused the greatest drop in yield $(17.9,17.3$ and $17.3 \%$, respectively) in moisture control conditions. Flag of the defoliation treatments in terms of stress after anthesis in the 'Chamran' cultivars (0.1\%) minimum and 'Parsi' and 'Marvdasht' cultivars (25.3 and 24.1\%) maximum yield loss created (Table 5). No reduction in grain yield due to removal of the flag leaf in the 'Chamran' and 'Pishtaz' show that likely in these cultivar, there is no resource constraints and perhaps remove of flag leaf in the cultivars stimulate the remobilization of this material stored stems the seed growing and or compensatory effect of other photosynthetic tissues including photosynthesis spike these conditions prevent a drop in yield has been.

1000 grain weight in the 'Pishgam' and 'Marvdasht' cultivars in remove flag leaf treatments showed a no decrease but an increase of about $4.2 \%$ and 'Zarin' cultivars the highest reduction $(6.8 \%)$ in the control condition this trait of Allocated. In stress after anthesis conditions 'Bahar' cultivars with $2.6 \%$ increased 1000 grain weight and 'Chamran' cultivars with $14 \%$ decrease the different reaction conditions showed. Remove the flag leaf in control conditions respectively cause increase and reduce the number of grains per spike 'Chamran' cultivar (6.5\%) and 'Marvdasht' (19.2\%). Also stress after anthesis cause increased the number of grains per spike 'Pishtaz', 'Chamran' and 'DN-11' cultivars (2.9, 2.7 and $2.7 \%$ ) and this feature reduces in 'Marvdasht' cultivar (18.6\%). Remove the flag leaf in control conditions, increasing the number of fertile spikelet per spike 'Chamran' cultivar (5\%) and reduce the number of fertile spikelets per spike 'Sivand' cultivar (20.3\%). In terms of stress, removes the flag leaf to enhance and reduce the number of fertile spikelets per spike 'Pishtaz' cultivar (2.7\%) and 'Marvdasht' cultivar (19.6\%) (Table 5).

Failure to reduce some of the traits, especially grain yield and 1000 grain weight the number of cultivars, probably this is due to the number of leaves removed from the flag leaf (reducing photosynthetic resources) need source to the other leaves or part of the plant photosynthetic including spike photosynthesis is supplied (Junmin et al., 1999; Mohamadtaheri et al., 2010) and or perhaps photosynthetic material before the flowering period the plant is stored stems by remobilization to grain transferred and order to prevent loss of yield and seed weight (Noshin et al., 1996; Janmohammadi et al., 2010).

\subsection{Treatment removal spikelet from one side of spike}

Treatments artificial removal of spikelets per spike in the number cultivar a review increased 1000 grain weight, yield per spike, number grain and number of fertile spikelets and reduce the number of infertile spikelet per spike was treated (Table 2). In control conditions in the non-treated spikelets remaining grain weight, 1000 grain weight, number of grains per spike and number of fertile spikelets after removal of one side spike respectively $23,9.1,12.4$ and $8.9 \%$ and in conditions of drought stress after anthesis 35.2, 21.8, 10.7 and 7.8\% showed an increase (Table 4), the results with the results Mahfoozi and Jasemi (2010) increase in grain weight within 50\% spikelet removal at the irrigation and drought stress of the growing season, was consistent. In other words, by removing one side of spikelet per spike compared with control, the average difference in grain weight per spike, 1000 grain weight, grain number per spike and spikelet fertility was significant, scilicet reducing the capacity of the reservoir (seed) traits is increased, therefore sink was not a limiting factor and the cultivar study limited supply of trained and transfer of resources.

Between cultivars study in terms of removing the seeds of a spike, yield spike cultivar 'Pishgam' maximum (35.6\%) and cultivar 'Sivand' and 'DN11' minimum (Both 11.4\%) increase showed in control conditions. In terms of stress after anthesis treatment to remove one side spike in all cultivars increased grain weight. In these circumstances the greatest increase 'Zarin' cultivar $(60.5 \%)$ and Minimal increase to 'Parsi' and 'Chamran' (18.7 and $18.6 \%$ ) (Table 5).

In the control condition highest increase in 1000 seed weight in the 'Pishgam' and 'Marvdasht' (19.9 and 15\%) and the lowest cultivar 'DN-11' $(0.4 \%)$ the control condition. In terms of stress after anthesis 'Marvdasht', 'Zarin', 'Bahar' and 'Pishtaz' cultivars most $(33.8,32.7,31.7$ and $31 \%$, respectively) and the lowest 'Chamran' cultivar $(1.3 \%)$ increase the 1000 grain weight. 
Removing the grains of one side spike in the control condition the greatest increase in the number of seeds remaining in the spike cultivar 'Zarin' and 'Chamran' (18.9 and 16.6\%) and the lowest increase in the number of grains per spike remaining 'Sivand' cultivar $(5.8 \%)$ grains per spike was not treated to remove. In terms of stress after anthesis treated grains removed, cultivar 'Zarin' the highest increase in the number of seeds remaining in the spike $(21.8 \%)$ and cultivar 'Parsi' the lowest.

Table 4: Variation in mean yield and its components in bread wheat cultivars as affected by the removal of spikelet from one side of spike and unremoval of spikelets under control water and water stress after anthesis conditions.

\begin{tabular}{|c|c|c|c|c|c|c|}
\hline \multirow[b]{2}{*}{ Traits } & \multicolumn{3}{|c|}{ Well water } & \multicolumn{3}{|c|}{ Water stress after anthesis } \\
\hline & Control & $\begin{array}{l}\text { Remove } \\
\text { one side } \\
\text { spike }\end{array}$ & $\begin{array}{c}\text { Changes of } \\
\text { control } \\
(\%)\end{array}$ & Control & $\begin{array}{c}\text { Remove } \\
\text { one side } \\
\text { spike }\end{array}$ & $\begin{array}{c}\text { Changes of } \\
\text { control } \\
(\%)\end{array}$ \\
\hline Grain yield (g/spike) & $1.87 \pm 0.10$ & $2.31 \pm 0.15$ & 23.0 & $1.50 \pm 0.06$ & $2.03 \pm 0.10$ & 35.2 \\
\hline 1000 grain weight $(\mathrm{g})$ & $42.3 \pm 1.2$ & $46.2 \pm 1.3$ & 9.1 & $33.1 \pm 1.4$ & $40.2 \pm 1.3$ & 21.8 \\
\hline Grain spike $^{-1}$ & $44.8 \pm 3.0$ & $50.3 \pm 3.5$ & 12.4 & $46.0 \pm 2.7$ & $50.9 \pm 3.2$ & 10.7 \\
\hline Fertile spikelet & $16.2 \pm 04$ & $17.7 \pm 05$ & 8.9 & $16.6 \pm 0.5$ & $18.0 \pm 0.5$ & 7.8 \\
\hline Non fertile spikelet & $2.45 \pm 0.30$ & $1.64 \pm 0.26$ & -33.3 & $2.05 \pm 0.27$ & $1.35 \pm 0.27$ & -34.4 \\
\hline
\end{tabular}

Data were means \pm SE.

Remove the seeds form one side spike the greatest reduction in the number of fertile spikelet per spike in the remaining 'Pishgam' and 'Chamran' cultivar $(12.4 \%)$ and reduce the minimum in the cultivar 'Sivand' (4.1\%). In terms stress cultivar 'Pishtaz' most (13.6\%) and 'Marvdasht' minimum (5\%) reduce the number of fertile spikelet at the showed a spike control.

Therefore, drought stress causes increasing resource limitation, the performance yield and 1000 grain weight. Other terminal drought stress additive effect on the resource constraints. Exacerbate resource constraints of drought stress during the reduced grain filling period (Koocheki et al., 2006), leaf senescence (Martinez et al., 2003; Gregersen and Holm, 2007) and reduction in leaf photosynthesis (Yang and Zhang, 2006).
According to the results obtained, likely resource constraints in modern bread wheat cultivar studied in the west region of Iran important factor in the potential of achieving high yield and to solve this problem should be followed cultivars with higher levels of green leaf and also leaf photosynthetic rate per unit area more in terms of the environment variable. Other ways of achieving cultivars storage materials with high photosynthetic in the stems before flowering and also it features high transfer material to the grain growing in terms of environment variable. The findings of Yang and Zhang (2006) and Yang et al. (2003) to achieve cultivars with high potential for remobilization in such environments is of best practices to sustain high performance. 
Majid ABDOLI et. al

Table 5: Mean comparison of interactions between irrigation regimes and treatments on agronomic traits in different improved wheat cultivars under post anthesis water deficiency.

\begin{tabular}{|c|c|c|c|c|c|c|c|c|c|c|c|c|c|c|c|c|c|c|c|c|c|}
\hline \multirow{2}{*}{ Cultivars } & \multirow{2}{*}{ Treatments } & \multicolumn{4}{|c|}{ Grain yield (g/spike) } & \multicolumn{4}{|c|}{1000 grain weight (g) } & \multicolumn{4}{|c|}{ Grain spike $^{-1}$} & \multicolumn{4}{|c|}{ Fertile spikelet } & \multicolumn{4}{|c|}{ Non fertile spikelet } \\
\hline & & water & $\begin{array}{c}\text { Changes } \\
(\%)\end{array}$ & stress & $\begin{array}{c}\text { Changes } \\
(\%)\end{array}$ & water & $\begin{array}{c}\text { Changes } \\
(\%)\end{array}$ & stress & $\begin{array}{c}\text { Changes } \\
(\%)\end{array}$ & water & $\begin{array}{c}\text { Changes } \\
(\%)\end{array}$ & stress & $\begin{array}{c}\text { Changes } \\
(\%)\end{array}$ & water & $\begin{array}{c}\text { Changes } \\
(\%)\end{array}$ & stress & $\begin{array}{c}\text { Changes } \\
(\%)\end{array}$ & water & $\begin{array}{c}\text { Changes } \\
(\%)\end{array}$ & stress & $\begin{array}{c}\text { Changes } \\
(\%)\end{array}$ \\
\hline \multirow[t]{3}{*}{ Bahar } & control & 1.84 & & 1.57 & & 40.7 & & 30.5 & & 45.2 & & 51.2 & & 17.0 & & 18.1 & & 2.3 & & 1.8 & \\
\hline & Remove flag leaf & 1.69 & -8.5 & 1.40 & -10.5 & 38.2 & -6.1 & 31.3 & 2.6 & 44.2 & -2.3 & 45.3 & -11.6 & 16.4 & -3.6 & 16.5 & -8.6 & 1.8 & -18.8 & 1.2 & -30.2 \\
\hline & Remove one side spike & 2.35 & 27.4 & 2.15 & 37.1 & 45.7 & 12.2 & 40.2 & 31.7 & 51.4 & 13.7 & 53.2 & 3.8 & 18.7 & 9.8 & 19.6 & 8.3 & 1.7 & -26.5 & 0.9 & -49.1 \\
\hline \multirow[t]{3}{*}{ Parsi } & control & 1.61 & & 1.45 & & 43.3 & & 35.5 & & 37.2 & & 40.5 & & 15.3 & & 15.5 & & 3.2 & & 2.3 & \\
\hline & Remove flag leaf & 1.56 & -3.2 & 1.08 & -25.3 & 41.9 & -3.2 & 31.1 & -12.5 & 37.2 & -0.1 & 34.8 & -14.1 & 15.2 & -0.2 & 13.8 & -11.2 & 2.7 & -13.6 & 2.0 & -10.9 \\
\hline & Remove one side spike & 1.98 & 22.7 & 1.72 & 18.7 & 49.4 & 14.1 & 42.5 & 19.9 & 40.1 & 7.8 & 40.5 & 0 & 16.4 & 7.1 & 16.5 & 6.4 & 2.4 & -24.2 & 2.4 & 4.3 \\
\hline \multirow[t]{3}{*}{ Pishtaz } & control & 1.77 & & 1.37 & & 46.0 & & 35.8 & & 38.3 & & 38.1 & & 15.0 & & 14.6 & & 3.0 & & 2.4 & \\
\hline & Remove flag leaf & 1.45 & -17.9 & 1.23 & -9.8 & 45.0 & -2.3 & 31.6 & -11.6 & 32.2 & -15.9 & 39.2 & 2.9 & 12.5 & -17 & 15.0 & 2.7 & 1.9 & -36.6 & 2.0 & -15.3 \\
\hline & Remove one side spike & 2.22 & 25.7 & 2.04 & 48.9 & 50.5 & 9.7 & 46.9 & 31 & 44.0 & 14.8 & 43.4 & 14.1 & 16.7 & 11.1 & 16.6 & 13.6 & 1.7 & -43.8 & 1.8 & -26.9 \\
\hline \multirow{3}{*}{ Pishgam } & control & 2.15 & & 1.95 & & 41.6 & & 36.8 & & 52.0 & & 52.6 & & 16.8 & & 17.7 & & 1.8 & & 1.3 & \\
\hline & Remove flag leaf & 2.23 & 3.7 & 1.59 & -18.4 & 43.4 & 4.2 & 31.6 & -14 & 51.3 & -1.3 & 50.1 & -4.9 & 16.6 & -0.8 & 17.3 & -2.2 & 1.3 & -29.8 & 1.1 & -19.5 \\
\hline & Remove one side spike & 2.91 & 35.6 & 2.39 & 22.5 & 49.9 & 19.9 & 43.8 & 19.2 & 58.3 & 12 & 54.5 & 3.6 & 18.8 & 12.4 & 19.2 & 8.7 & 0.8 & -54.3 & 0.8 & -40 \\
\hline \multirow[t]{3}{*}{ Chamran } & control & 1.43 & & 1.34 & & 43.8 & & 37.9 & & 32.6 & & 35.4 & & 14.5 & & 15.5 & & 4.0 & & 3.7 & \\
\hline & Remove flag leaf & 1.50 & 4.8 & 1.34 & -0.1 & 43.3 & -1.3 & 37.0 & -2.5 & 34.7 & 6.5 & 36.4 & 2.7 & 15.2 & 5 & 15.3 & -1.2 & 3.5 & -14 & 3.0 & -19.7 \\
\hline & Remove one side spike & 1.69 & 18.3 & 1.59 & 18.6 & 44.7 & 2 & 38.4 & 1.3 & 38.0 & 16.6 & 41.4 & 16.8 & 16.3 & 12.4 & 16.4 & 6 & 2.7 & -33.9 & 2.2 & -40.2 \\
\hline \multirow[t]{3}{*}{ Zarin } & control & 2.41 & & 1.61 & & 41.9 & & 28.4 & & 57.5 & & 56.3 & & 18.0 & & 18.2 & & 1.8 & & 1.4 & \\
\hline & Remove flag leaf & 2.03 & -15.7 & 1.44 & -11.1 & 39.1 & -6.8 & 27.8 & -2.2 & 52.1 & -9.4 & 51.3 & -8.8 & 15.7 & -12.8 & 15.5 & -14.4 & 1.1 & -36.3 & 0.8 & -41.5 \\
\hline & Remove one side spike & 3.01 & 24.9 & 2.59 & 60.5 & 44.0 & 5 & 37.7 & 32.7 & 68.3 & 18.9 & 68.5 & 21.8 & 19.8 & 10 & 19.3 & 6.4 & 0.8 & -54.7 & 0.4 & -71.4 \\
\hline \multirow[t]{3}{*}{ Sivand } & control & 1.84 & & 1.35 & & 47.5 & & 34.2 & & 38.8 & & 39.6 & & 15.4 & & 15.2 & & 2.8 & & 2.4 & \\
\hline & Remove flag leaf & 1.52 & -17.3 & 1.14 & -16.1 & 45.0 & -5.4 & 31.3 & -8.5 & 33.8 & -12.8 & 36.0 & -8.9 & 13.3 & -13.5 & 13.8 & -9 & 2.2 & -20.1 & 1.9 & -23.4 \\
\hline & Remove one side spike & 2.05 & 11.2 & 1.84 & 35.5 & 50.0 & 5.1 & 41.2 & 20.5 & 41.0 & 5.8 & 44.4 & 12.1 & 16.0 & 4.1 & 17.0 & 11.8 & 2.5 & -11.9 & 1.9 & -23.3 \\
\hline \multirow[t]{3}{*}{ Marvdasht } & control & 2.00 & & 1.40 & & 35.4 & & 25.3 & & 56.5 & & 55.2 & & 17.8 & & 18.6 & & 1.0 & & 1.0 & \\
\hline & Remove flag leaf & 1.68 & -15.9 & 1.06 & -24.1 & 36.9 & 4.2 & 23.5 & -7 & 45.6 & -19.2 & 44.9 & -18.6 & 14.3 & -20.1 & 14.9 & -19.6 & 0.6 & -39.7 & 0.5 & -50.4 \\
\hline & Remove one side spike & 2.52 & 26 & 2.05 & 47.1 & 40.8 & 15 & 33.9 & 33.8 & 62.0 & 9.7 & 60.6 & 9.8 & 19.1 & 7.1 & 19.5 & 5 & 0.5 & -50 & 0.2 & -83.3 \\
\hline \multirow[t]{3}{*}{$\mathrm{DN}-11$} & control & 1.82 & & 1.49 & & 40.6 & & 33.1 & & 44.9 & & 45.0 & & 16.4 & & 16.5 & & 2.3 & & 2.1 & \\
\hline & Remove flag leaf & 1.51 & -17.3 & 1.44 & -3.5 & 39.8 & -1.9 & 31.1 & -5.9 & 37.8 & -15.7 & 46.3 & 2.9 & 13.6 & -17.3 & 16.3 & -1.1 & 1.7 & -26.7 & 1.8 & -13.7 \\
\hline & Remove one side spike & 2.03 & 11.4 & 1.93 & 29.3 & 40.7 & 0.4 & 37.6 & 13.6 & 49.7 & 10.8 & 51.5 & 14.4 & 17.3 & 5.7 & 17.3 & 5.3 & 1.7 & -23.5 & 1.6 & -23.8 \\
\hline \multirow{2}{*}{\multicolumn{2}{|c|}{$\frac{\operatorname{LSD}(0.05)}{\mathrm{CV}(\%)}$}} & \multicolumn{4}{|c|}{0.48} & \multirow{2}{*}{\multicolumn{4}{|c|}{$\begin{array}{l}7.74 \\
7.13\end{array}$}} & \multicolumn{4}{|c|}{4.52} & \multicolumn{4}{|c|}{0.48} & \multicolumn{4}{|c|}{0.53} \\
\hline & & \multicolumn{4}{|c|}{10.8} & & & & & & & & & & & & & & & & \\
\hline
\end{tabular}

180 Acta agriculturae Slovenica, 101 - 2, september 2013 


\section{ACKNOWLEDGMENTS}

The authors would like to thank their colleagues in Agricultural and Natural Resource, university of Razi, Kermanshah.

\section{REFERENCES}

Acreche, M.M., Slafer, G.A. 2006. Grain weight response to increases in number of grains in wheat in a Mediterranean area. Field Crops Research. 98(1): 52-59.

Aggarwal, P.K., Chaturvedi, Q.S., Singh, A.K., Sinha, S.K. 1986. Performance of wheat and triticale cultivars in a variable soil-water environment. II: Source-Sink relationships. Field Crops Research. 13: 317-330.

Ahmadi, A., Joudi, M., Tavakoli, A., Ranjbar, M. 2009 a. Investigation of yield and its related morphological traits responses in wheat genotypes under drought stress and irrigation conditions. Journal of Science and Technology of Agriculture and Natural Resources. 12(46): 155-166.

Alam, M.S., Rahman, A.H.M., Nesa, M.N., Khan, S.K., Siddquie, N.A. 2008. Effect of source and/or sink restriction on the grain yield in wheat. Journal of Applied Sciences Research. 4(3): 258-261.

Araus, L.A., Slafer, G.A., Reynolds, M.P., Royo, C. 2002. Plant breeding and drought in $\mathrm{C}_{3}$ cereals: what should we breed for? Ann Bot. 89: 925-940.

Biade, S.F., Baker, R.J. 1991. Kernel weight response to source-sink changes in spring wheat. Crop Sciences. 31: 1117-1120.

Birsin, M.A. 2005. Effects of Removal of Some Photosynthetic Structures on Some Yield Components in Wheat. Tarim Bilimleri Dergisi. 11: 364-367.

Blum, A., Mayer, J., Golan, G. 1988. The effect of grain number per ear (sink size) on source activity and its water-relations in wheat. Journal of Experimental Botany. 39: 106-114.

Blum, A., Polarkova, H., Golan, G., Mayer, J. 1983. Chemical desiccation of wheat plants as simulators of post-anthesis stress: I. Effects on translocation and kernel growth. Field Crops Research. 6: 51-58.

Borra's, L., Slafer, G.A., Otegui, M.E. 2004. Seed dry weight response to source-sink manipulations in wheat, maize and soybean: a quantitative reappraisal. Field Crops Research. 86: 131-146.

Calderini, D.F., Reynolds, M.P. 2000. Changes in grain weight as a consequence of de-graining treatments at pre and post anthesis in synthetic hexaploid lines of wheat (Triticum durum and T. tauschii). Australian Journal of Plant Physiology. 27: 183-191.

Cruz-Aguado, J.A., Reyes, F., Rodes, R., Perez, I., Dorado, M. 1999. Effect of source-to-sink ratio on partitioning of dry Matter and ${ }^{14} \mathrm{C}$-photoassimilates in wheat during grain filling. Annuals of Botany. 83: 655-665.
Duggan, B.L., Domitruk, D.R., Fowler, D.B. 2000. Yield component variation in winter wheat grown under drought stress. Can. Plant Sciences. 80: 739-745.

Ehdaie, B., Alloush, G.A., Madore, M.A., Waines, J.G. 2006 a. Genotypic variation for stem reserves and mobilization in wheat: I. post anthesis changes in internode dry matter. Crop Sciences. 46:735-746.

Ehdaie, B., Alloush, G.A., Madore, M.A., Waines, J.G. 2006 b. Genotypic variation for stem reserves and mobilization in wheat: II. Post anthesis changes in internode watersoluble carbohydrate. Crop Sciences. 46: 2093-2103.

Ercoli, L., Lulli, L., Mariotti, M., Masoni, A., Arduini, I. 2007. Post anthesis dry matter and nitrogen dynamics in durum wheat as affected by nitrogen supply and soil water availability. European Journal of Agronomy. 28: 138147.

Esmaielpur, M. 2007. Response of tow wheat cultivars to source size modification: interaction of cultivars and plant density under water stress and non-stress condition. M. Sc. thesis, College of Agriculture, University of Tehran, Karaj.

Fischer, R.A. 2008. The importance of grain or kernel number in wheat: A reply to Sinclair and Jamieson. Field Crops Research. 105: 15-21.

Fischer, R.A., Aquilar, I., Laing, D.R. 1977. Post-anthesis sink size in high yielding dwarf wheat, yield response to grain number. Australian Journal of Agricultural Research. 28: 165-175.

Gallaghe, E.J. 1984. Cereal Production. Butterworths. 354 pp.

Gregersen, P.L., Holm, P.H. 2007. Transcriptome analysis of senescence in the flag leaf of wheat. Plant Biotechnology. 5: 192-206.

Heidari-Sharifabad, H. 2008. Drought mitigation strategies for the agriculture sector. The $10^{\text {th }}$ Iranian Congress of Crop Sci. 18-20 Aug. 2008, SPII, Karaj, Iran.

Janmohammadi, M., Ahmadi, A., pustyni, K. 2010. The effect of reducing leaf area and nitrogen on wheat flag leaf stomatal characteristics and performance under irrigation. Journal of Crop Production. 3(4): 177-194.

Jones, M.G. 2009. Using resources from the model plant Arabidopsis thaliana to understand effects of abiotic stress. Salinity Water Stress. 44: 129-132.

Junmin, J., Hua-Guo, H., Xu, H., Ji-Chun, D., Jiang, J.M., Hua, G.H., Xu, H.J., Ji, C.D. 1999. Effects of different treatments on dry matter production after heading and

Acta agriculturae Slovenica, 101 - 2, september 2013 
grain yield in wheat. Acta Agriculture Shanghai. 15(1): 83-86.

Kobata, T., Palta, J.A., Turner, N.C. 1992. Rate of development of post anthesis water deficits and grain filling of spring wheat. Crop Sciences. 32: 1238-1242.

Koocheki, A.R., Yazdansepas, A., Nikkhah, H.R. 2006. Effects of terminal drought on grain yield and some morphological traits in wheat (Triticum aestivum L.) genotypes. Iranian Journal of Agriculture Sciences. 8: 1429.

Mahfoozi, S., Jasemi, S. 2010. Study of the possibility of increasing grain yield by increasing grain weight in winter and facultative wheat genotypes with manipulating sink capacity. Iranian Journal of Crop Sciences. 12(1): 76-84.

Martinez, D.E., Luquez, V.M., Bartoli, C.G., Guiamét, J.J. 2003. Persistence of photosynthetic components and photochemical efficiency in ears of water-stressed wheat (Triticum aestivum). Physiology Plant. 119: 1-7.

Miralles, D.J., Slafer, G.A. 1995. Yield, biomass and yield components in dwarf, semi-dwarf and tall isogonic lines of spring wheat under recommended and late sowing dates. Plant Breeding. 114: 392-396.

Mohamadtaheri, M. 2008. Determine the critical level of resource constraints in modern and ancient commercial varieties of wheat, modified for cold regions, and warm temperate. MS Thesis of Agriculture, Department of Agriculture, Tehran University. Iran.

Mohamadtaheri, M., Ahmadi, A., pustyni, K. 2010. Old and new varieties of wheat response temperate, warm andcold cuts power supply to Iran. Iranian Journal of Crop Sciences. 41(2): 271-280.

Noshin, B., Hac, I.U., Shap, P. 1996. Source reduction and comparative sink enhancement effects on remobilization of assimilates during seed filling of old and new wheat varieties. Rachis. 15: 20-23.

Radmehr, M., Lotf-Ali, G., Aeyneh, A., Naderi, A. 2004. A study on source-sink relationship of wheat genotypes under favorable and terminal heat stress conditions in Khuzestan. Iranian Journal of Crop Sciences. 6(2): 101114.

Reynolds, M., Calderini, D., Condon, A., Vargas, M. 2007. Association of source/sink traits with yield, biomass and radiation use efficiency among random sister lines from three wheat crosses in a high yield environment. Journal of Agricultural Science. 145: 3-16.

Royo, C., Miloudi, M.M., Fonze, N.D., Arraus, J.L., Pfeiffer, W.H., Slafer, G.A. 2005. Durum wheat breeding current approaches and future strategies. Vol 1. Editors: Food product press.

Saeidi, M., Moradi, F., Ahmadi, A., Spehri, R., Najafian, G., Shabani, A. 2010. The effects of terminal water stress on physiological characteristics and sink-source relations in two bread wheat (Triticum aestivum L.) cultivars. Iranian Journal of Crop Sciences. 12(4): 392-408.

Saeidi, M., Moradi, F., Jalali-Honarmand, S. 2012. The effect of post anthesis source limitation treatments on wheat cultivars under water deficit. Australian Journal of Crop Science. 6(7): 1179-1187.

Shah, N.H., Paulsen, G.M. 2003. Interaction of drought and high temperature on photosynthesis and grain-filling of wheat. Plant and Soil. 257: 219-226.

Steel, R.G.D., Torrie, J.H., Dickey, D.A. 1997. Principles and procedures of statistics. 3rd ed. McGraw-Hill, New York.

Tavakoli, A., Ahmadi, A., Alizade, H. 2009. Some aspects of physiological performance of sensitive and tolerant cultivars of wheat under drought stress conditions after pollination. Iranian Journal of Crop Sciences. 40(1): 197211.

Wardlaw, F. 1980. Translocation and source-sink relationships. In (eds) The biology of crop productivity. Academic press (New York): 297-333.

Winkel, A. 1989. Breeding for drought tolerance in cereals. Vortage-Fur-Pflanzenzvchtuny. 16: 368-375.

Yang, J., Zhang, J. 2006. Grain filling of cereals under soil drying. New Phytologist. 169: 223-236.

Yang, J., Zhang, J., Wang, Z., Liu, L., Zhu, Q. 2003. Postanthesis water deficits enhance grain filling in two-line hybrid rice. Crop Science. 43: 2099-2108.

Zhu, G.X., Midmore, D.J., Radford, B.J., Yule, D.F. 2004. Effect of timing of defoliation on wheat (Triticum aestivum) in central Queensland. Field Crops Research. 88: 211-226. 